Open access $\oint$ free available online

\title{
Entrevista/Interview/Entrevista
}

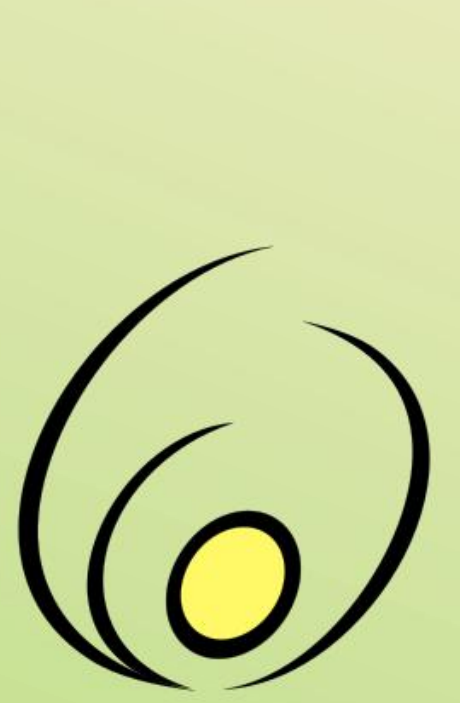

Fórum de

Pró-Reitores

de Extensão

das Instituições

Públicas de

Educação Superior

Brasileiras
Revista Brasileira de Extensão Universitária/ Brazilian Journal of University Extension

v. 8 , n. 1, p. 57-61 (2017)

e-ISSN 2358-0399

DOI: https://doi.org/10.24317/2358-0399.2017v8i1.4993

\section{The Scholarship of Engagement and}

\section{University Extension at the University of}

\section{Alberta}

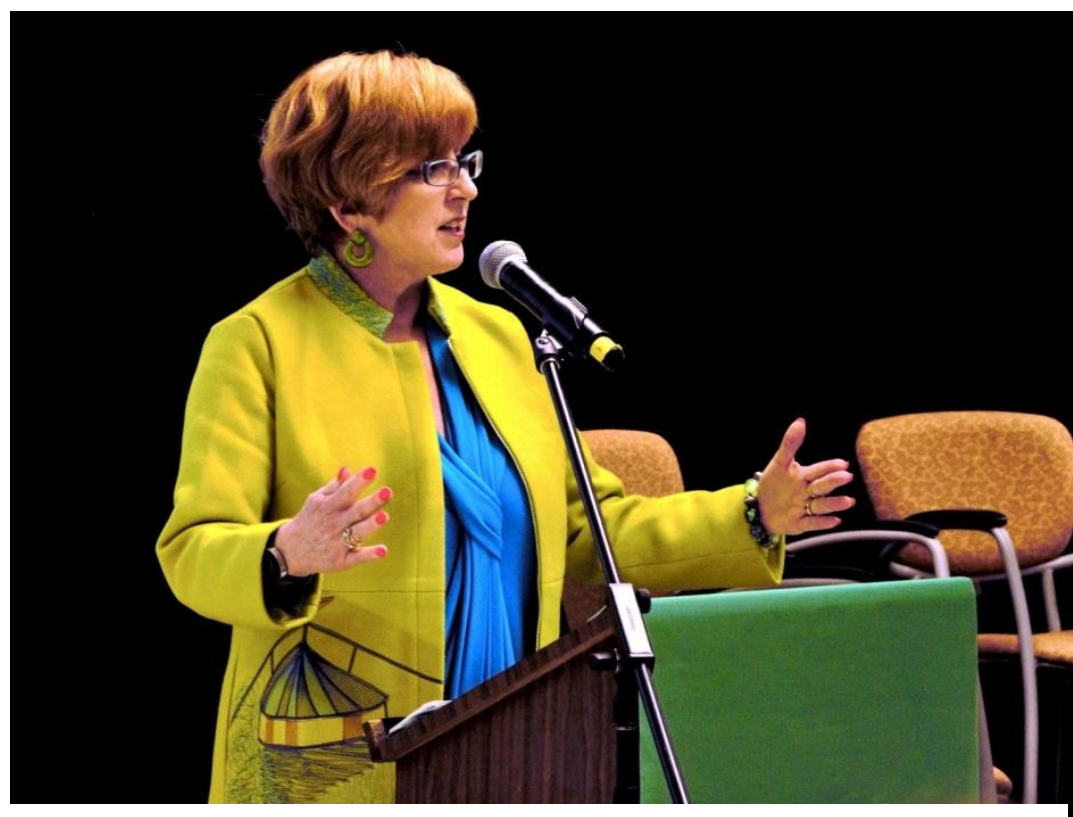

Interviewed: Katy Campbell

Dr. Katy Campbell, Professor, has served as the Dean of the Faculty of Extension at the University of Alberta, Canada, since 2009. Before that she was Interim Dean (2007-2009), Associate Dean (2001-2007), and Director of Academic Technologies for Learning, a faculty development unit, from 1999-2003.

Born and raised in Edmonton, Alberta, she received her $\mathrm{PhD}$ (1994) in Instructional Studies from the University of Alberta. She joined the Faculty of Extension in 1996; in 2008 she led the development of a new academic plan emphasizing university-community engagement and the scholarship of engagement. Since then the Faculty has focused on faculty renewal, requiring all new faculty members to contribute to the 
engagement scholarship domain and to demonstrate social impact in their annual evaluation reports. Four of these faculty members comprise the Community-University Partnership for the Study of Children, Youth and Family (CUP), which is guided by a steering committee that represents 13 communities and eight University departments. The Faculty has also launched Canada's first graduate program in community engagement, the Master of Arts in Community Engagement. The graduate degree suite also includes a graduate certificate and additional programs that can be laddered into degrees in other departments and institutions.

Dr. Campbell led the University of Alberta team in the eight-university pan-Canadian consortium Rewarding Community-Engaged Scholarship: Towards the Transformation of University Policies and Practices, and represents the University on the board of the Engagement Scholarship Consortium as well as on the executive board of the Academy of Community Engagement Scholars (ACES). She has also represented the University of Alberta on initiatives such as Racism Free Edmonton, Edmonton Region Immigrant Employment Council, Equal Voice (Alberta North), and Edmonton Business Diversity Network. Other University citizenship activities include participation on UAlberta's advisory committees for sustainability and equity/diversity. Dr. Campbell's term as Dean of the Faculty of Extension was renewed in 2014.

Prior to joining the University of Alberta, Dr. Campbell was assistant professor at the State University of New York, Ella Cline Shear School of Education, Geneseo (SUNY-Geneseo, 1993-1995), and a distance education specialist at Keewatin Community College in northern Canada. An instructional designer by education and inclination, she works with narrative and autoethnography within a feminist, post-structural theoretical framework, examining the socially constructed nature of instructional design in higher education and cross-cultural settings. She is primarily interested in questions of cultural identity (especially gender), agency, identity, and social change.

Here she tells us the meaning of 'engagement scholarship' in her context and discusses the university extension roles at the University of Alberta.

\section{Revista Brasileira de Extensão Universitária} (RBEU): What does 'engagement scholarship' mean and what is its importance within the University of Alberta and in Canada?

Katy Campbell: The scholarship of engagement is an academic model, or intellectual domain, first articulated by Ernest Boyer in 1990 (c.f. Boyer, $1996^{1}$ ). The model advocates expanding the traditional definition of scholarship and research, generally agreed to be based on the work of Humboldt, into four types of scholarship. According to Boyer, traditional research, or the scholarship of discovery, had been the center of academic life and crucial to an institution's advancement, currently dominating global university rankings. However, the original intent of establishing land-grant universities, for example, in the United States, was to build capacity in society to address issues and challenges of public interest and concern. Boyer argued that although these institutions were funded by public taxes, they had been increasingly withdrawing from authentic interaction with the public (i.e. had become "ivory towers"). In other words, scholarship needed to be broadened and made more flexible to include not only the new social and environmental challenges beyond the campus but also the reality of complex, global, multifaceted problems. A more relevant and potentially effective approach embraces the mutually beneficial and reciprocal co-creation and mobilization of knowledge. The proposed categories include:

- scholarship of discovery, i.e. original research that advances knowledge;

- scholarship of integration, i.e. the synthesis of information across disciplines, across topics within a discipline, or across time; currently characterized as interdisciplinarity;

- scholarship of application (the scholarship of engagement) that involves the rigor and application of disciplinary expertise with results that can be shared with and/or evaluated by peers; and 
- scholarship of teaching and learning, or the systematic study, and public sharing, of teaching and learning processes.

In North America the scholarship of engagement is often aligned with experiential and service-based (community) learning, although there are distinct cultural differences in the understanding, assessment, and authority of these practices. The Faculty of Extension at the University of Alberta built our Strategic Plan on the following definition of community-based research, from a task force report (2006) at the University of Victoria, BC, Canada.

\footnotetext{
"research... [that] seeks to democratize knowledge creation by validating multiple sources of knowledge and promoting the use of multiple methods of discovery and dissemination."
}

The Faculty of Extension elaborated on this definition by proposing that transforming societal communities and organizations (including the University) into learning communities is scholarly, integrative, transformational, and action-oriented, and equips us all for more effective citizenship that includes social action. We also distinguish between community engaged research and engagement scholarship. The latter is a scholarly discipline identifying, creating, implementing, and evaluating methods and protocols for engaging communities in mutually designed research of benefit to the community. The scholarship - the study and application of the phenomena, processes, pedagogies, policies, and practices of effective university/community engagement - informs, builds capacity in, and is realized in the activities and sites of community-engaged learning, discovery and citizenship. While many scholars in a university may use community-based research methods, not all of them study the phenomena of engagement itself.

"The scholarship of
engagement recasts
teaching, research and
service as learning,

discovery and citizenship."
RBEU: How are the concepts of extension, outreach, service-learning and engagement scholarship related? Are there any overlaps between them?

KC: There definitely is overlap between these concepts and, in fact, "outreach" defined the role and practices of the Faculty of Extension for at least 80 years. Our Faculty was established to "take the University to the people," or translate academic research into practical applications (historically, agriculture) and learning opportunities that were more flexible than degree programs. Our founding President, Henry Marshall Tory, was committed to the idea of equitable access to knowledge for all, so over time our Faculty has led innovation in adult learning, technology-based learning, distributed learning, prior learning assessment, program evaluation, laddering credentials (e.g. non-credit to credit), etc. The intent of this activity was community capacity-building through teaching, research and service that responds to the aspirations and concerns of community members who are external to the "traditional" boundaries of university campuses. The University of Alberta supports numerous engaged scholars in Faculties other than Extension; these individuals may teach, do research in, and serve in many diverse communities. The scholarship of engagement, on the other hand, recasts teaching, research and service as learning, discovery and citizenship. Its purposes are to improve the processes and practices of engaged scholarship and/or to contribute to scholarly and professional understanding of them. Relatively few scholars do this. The democratization of knowledge - its creation, ownership, and mobilization - are at the centre of this domain, whereas in outreach the creation of knowledge (and often ownership) typically belongs to the University and is assessed by a limited community of disciplinary peers. I must note here that in Canada, and in the US as well, as public funding has decreased departments/Faculties like ours have been increasingly pressured to generate revenue for the University; i.e. support the neoliberal rather than social action agenda. A discussion of the impacts of this movement can be found in McLean, Thompson, $\&$ Jonker $^{2}$. Finally, service-learning in Canada and the States seems to be mostly located in undergraduate programs and is coming under criticism now, particularly from critical theorists/scholars in the UK (c.f. Tara Fenwick), and from communities like indigenous communities in Canada. At the University of Alberta servicelearning infrastructure is based out of the Faculty of Arts. ${ }^{3}$ 
${ }^{66}$ To support, and reward, engagement scholarship we substantially revised our policies and procedures for tenure and promotion."

RBEU: Does participation in engagement scholarship impact professional formation? Is it acknowledged in the $\mathrm{U}$ of $\mathrm{A}$ and other universities?

KC: I am not sure if you are speaking of the transformation of the academic or scholar, or the impact of this model on professional development in, for example, engineering, law, etc. If you are referring to the "new" engagement scholar, yes, this turn in thinking and practice is beginning to, or at last has the potential to be, profoundly disruptive to the traditional higher education model. However, an enduring problem is the way in which faculty members are evaluated. To support, and reward, engagement scholarship we substantially revised our policies and procedures for tenure and promotion. For example, we acknowledge external research funding and peer-reviewed publications in high impact journals as "inputs" and "outcomes" respectively, but more importantly we want to see the social impact. Of course, that is much harder to define and assess: impact is seen over time, cannot necessarily be attributed to one individual (because engaged scholarship and engagement scholarship require partnerships), it is in the public domain, it does not easily lend itself to metrics, and so on. So, part of engagement scholarship is defining and describing the social return on investment.

RBEU: Why is the Faculty of Extension a separate unity at the $\mathrm{U}$ of $\mathrm{A}$ and in other Canadian universities? How is the relationship of the Faculty of Extension with other units and Faculties within the $\mathrm{U}$ of $\mathrm{A}$ ?

KC: At the University of Alberta, the Faculty of Extension is an academic unit like every other Faculty, with tenure-stream faculty, graduate programs, etc. We position ourselves as capacity- builders both inside and outside the University. In a sense, we are also a centre for disruption and innovation; we are inherently interdisciplinary, know how to engage with and meet community needs through sustainable partnerships and programs that, overall, break even, financially. We contribute positively to the University rather than being a site of expense. For example, our base budget is very small and we support our activities, and collaborations with other units, with costrecovery activities, partnerships with other organizations and private industry, and in other ways. We take the risks that other units are not willing to take because we keep innovations controlled in a pilot, evaluate it, develop a business plan, and so on. That is one reason why we are usually the group involved in supporting new and emerging professions. University Extension is originally an American model (aka the Wisconsin model) that was adapted in Western Canada. But there are many other models in Canada alone that are culturally and socially situated. Social activism, democratization of knowledge, supporting marginalized communities, pluralism and decolonizing knowledge is more Canadian than the American model of economic capacity building and civic education. Having said that, there are now very few academic Faculties entirely focused on Extension left in Canada and almost none in the United States, Australia, and the UK. This work may be taken up by continuing education units. Currently, Canadian institutions are in various stages of understanding and implementing the Truth and Reconciliation Commissions recommenddations ${ }^{4}$. This is informing much of our work.

\section{Notes:}

1. BOYER, E. L. The scholarship of engagement. Journal of Public Service and Outreach, v. 1, p. 11-20, 1996.

2. MCLEAN, S.; THOMPSON, G.; JONKER, P. The rising tide of outreach and engagement in state and land-grant universities in the United States: What are the implications for University Continuing Education Units in Canada? Canadian Journal of University Continuing Education, v. 32, n. 1, p. 83-108, 2006. 
3. We are very interested in cultural interpretations and implementations of "engagement." The comments I have made are from my "dominant culture" perspective, of which I am painfully aware through my feminist work, and my international relationships.

4. Available at < http://www.trc.ca/websites/trcinstitution /File/2015/Honouring_the_Truth_Reconciling_for_th e_Future_July_23_2015.pdf >

This interview was granted via internet to the editor Geraldo Ceni Coelho (cenicoelho@gmail.com), professor at the Universidade Federal da Fronteira Sul at Chapecó, Santa Catarina State, Brazil.

\footnotetext{
How to cite this interview:

CAMPBELL, K. The Scholarship of Engagement and University Extension at the University of Alberta. Interview granted to Geraldo Ceni Coelho. Revista Brasileira de Extensão Universitária, v. 8, n. 1, p. 57-61, 2016. Available at: < https://periodicos.uffs.edu.br/index.php/RBEU/interview/ view /4993/pdf $>$
} 